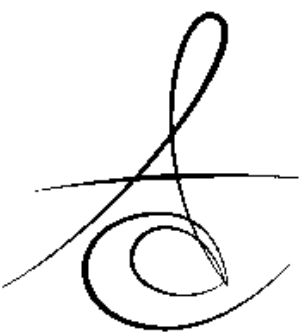

\title{
THE DETERMINATION OF SAFE ZONE FOR HORIZONTAL RAMUS CUT IN SAGITTAL SPLIT RAMUS OSTEOTOMY WITH CONE BEAM COMPUTED TOMOGRAPHY: A RETROSPECTIVE PILOT STUDY
}

\section{SAGİTTAL SPLİT RAMUS OSTEOTOMİSİNDE RAMUS KESİSİ İÇi̇N GÜVENİLİR SINIRLARIN KONİK IŞINLI BİLGİSAYARLI TOMOGRAFİ İLE BELİRLENMESİ: RETROSPEKTİF PİLOT ÇALIŞMA}

\author{
Dr. Öğr. Üyesi İbrahim Şevki BAYRAKDAR*
}

Dr. Öğr. Üyesi Elif BİLGİR*

Makale Kodu/Article code: 3812

Makale Gönderilme tarihi: 28.08.2018

Kabul Tarihi: 05.12.2018

\section{ABSTRACT}

Aim: Bilateral sagittal split ramus osteotomy (BSSRO) is commonly used to correct mandibular deformities. The first cut for this osteotomy is performed on the medial aspect above the lingula. During this procedure; The most feared intraoperative complication, the undesired fracture. Most of the BSSRO complications consist of condyle fracture or buccal/lingual plate fracture. The aim of this study was to determined the distance between the lingula and the sigmoid notch which is a surgical importance for BSSRO.

Material and Methods: This retrospective study composed of the cone beam computed tomography images that were obtained at the our clinic. The sample compromised 70 patients (32 males and 38 females, with an age range of 12 to 28 years). The perpendicular distance between the fixed plane and upper limit of lingula was measured. The sample comprised 70 subjects ( 32 males and 38 females, with an age range of 12 to 28 years). The obtained data were statistically evaluated.

Results: The minimum distance of the between fixed plane passing from sigmoid notch with lingula was found as a minimum of $4.80 \mathrm{~mm}$ and a maximum of $19.20 \mathrm{~mm}$ (mean \pm std. dev. $=11.99 \mathrm{~mm} \pm 2.40, \mathrm{n}=140$ ). The right and left side measurement ranged from $4.80 \mathrm{~mm}$ to $16.4 \mathrm{~mm}$ (mean \pm std. dev $=11.34 \mathrm{~mm} \pm 2.26$, $\mathrm{n}=70$ ) and $7.72 \mathrm{~mm}$ to $19.20 \mathrm{~mm}$ (mean \pm std. dev.= $12.64 \mathrm{~mm} \pm 2.39, \mathrm{n}=70)$, respectively.

Conclusion: The findings obtained in this study provide a guideline for surgeons performing BSSRO on young populations in Turkey. Pre-procedural threedimensional evaluation provides valuable information to prevent undesirable fractures.

Keywords: Horizontal Ramus Osteotomy, CBCT, Sagittal Split Osteotomy

\section{öz}

Amaç: Bilateral sagittal split ramus osteotomisi, mandibular deformiteleri düzeltmek için sıklıkla kullanılan cerrahi bir yöntemdir. Bu osteotomi için ilk kesi lingula üzerinden geçen bir hat üzerinde gerçekleştirilir. Bu cerrahi sırasında en korkulan intraoperatif komplikasyon istenmeyen kırık oluşumudur. Operasyon esnasında hem proksimal hem de distal segmentlerde kırık oluşabilir. Bu çalışmanın amacl, güvenli bir bilateral sagittal split ramus osteotomisi için cerrahi önemi olan lingula ve sigmoid çentik arasındaki mesafeyi belirlemektir.

Gereç ve Yöntem: Bu retrospektif çalışma, kliniğimizde çeşitli dental sebeplerle elde edilen konik ışınlı bilgisayarlı tomografi görüntüleri üzerinde gerçekleştirildi.

Aksiyel düzlem, sigmoid çentikten geçecek şekilde konumlandırılarak, oluşturulan sabit düzlem ile lingula üst sınırı arasındaki dikey mesafe ölçüldü. Örneklem 70 kişinin (12-28 yaş aralığında, 32 erkek, 38 kadın) verilerini içermekteydi. Veriler istatistiksel olarak değerlendirildi.

Bulgular: Minimum mesafe $4.8 \mathrm{~mm}$ maksimum mesafe $19 \mathrm{~mm}$ olarak bulundu (ort \pm std sapma=11,99 $\mathrm{mm} \pm 2.40, \mathrm{n}=140$ ). Sağ ve sol taraf ölçümleri sırasıyla $4.80 \mathrm{~mm}$ 'den $16.4 \mathrm{~mm}^{\prime}$ ye (ort \pm std. sapma $=11.34 \mathrm{~mm} \pm$ 2.26, $\mathrm{n}=70$ ), $7.72 \mathrm{~mm}^{\prime}$ den $19.20 \mathrm{~mm}$ 'ye (std. dev.= $12.64 \mathrm{~mm} \pm 2.39, \mathrm{n}=70$ ) değişmekteydi.

Sonuç: Bu çalışmada elde edilen bulgular genç Türk popülasyonuna bilateral sagittal split ramus osteotomisi için cerrahlara bir rehber olabilir. Prosedür öncesi üç boyutlu değerlendirme, istenmeyen fraktürlerin önlenmesinde değerli bilgiler sağlar.

Anahtar Kelimeler: Horizontal Ramus Kesisi, KIBT, Sagittal Split Osteotomisi

\footnotetext{
* Department of Dentomaxillofacial Radiology, Faculty of Dentistry, Eskişehir Osmangazi University, Eskişehir.
} 


\section{INTRODUCTION}

Bilateral sagittal split ramus osteotomy (BSSRO) is commonly used to correct mandibular deformities, such as mandibular retrognathism or prognathism ${ }^{1-3}$. In 1957 Trauner and Obwegeser started popularizing the BSSRO. The technique has been modified by Dal Pont (1961) ${ }^{4}$, Hansuck (1968) ${ }^{5}$, and Epker (1977) ${ }^{6}$.

The complications of BSSRO can be subdivided into such categories as vascular, neural, infectious, occlusal, and dental. They can also manifest as dysfunctional TMJ, undesired fractures (bad split), fixation complications, or any combination of those. The most feared intraoperative complication, the undesired fracture, has been reported in up to $20 \%$ of patients ${ }^{7}$, and this type fracture may develop in the proximal or distal segment (most of the complications consist of condyle fracture or buccal/ lingual plate fracture). The experienced orthognathic surgeon has encountered at least once the horizontal ramus cut, the distal segment vertical fracture (fracture of the lingual plate), or the fracture of the medial condyle and neck ${ }^{8}$.

The first cut for this osteotomy is performed on the medial aspect above the lingula. During this procedure; besides the undesired fracture that may occur during this procedure, the most feared complication is lingual nerve damage or neurosensorial disturbances. Postoperative instability, relapse, or dysfunction of the mandible with consecutive impairment can also lead to the development of temporomandibular joint dysfunction. With efforts to prevent bad splits, old age, a thin osteotomy site, a high mandibular lingula, a lack of attention from the surgeon, and incorrect inclination of the osteotomy are possible risk factors to undesired fracture. Therefore, knowledge about the anatomical characteristics of the mandible, undesired fracture and nerve damages can provide considerable insight into the osteotomy sites and prevention of complications ${ }^{9}$. The aim of this study was to determined the distance between the sigmoid notch and the lingula which is a surgical importance for BSSRO.

\section{MATERIALS AND METHODS}

This study composed of the CBCT images that were obtained at the Eskişehir Osmangazi University Dentistry Faculty as retrospective and as low as reasonably achievable principle (ALARA) was applied on the taking of all CBCTs on patients. The Non-Interventional Clinical Research Ethics Committee of Eskisehir Osmangazi University, Medicine Faculty approved this study with decision no: 112 , dated: 20.04.2018.

All of the patients had been admitted to the diagnosis and treatment planning of various troubles involving the dento-maxillofacial region. The sample comprised 70 subjects ( 32 males and 38 females, with an age range of 12 to 28 years). All tomographic images were obtained in a standard supine position by using CBCT machine (Planmeca Promax 3D mid, Helsinki, Finland). The exclusion criteria were include; craniofacial syndromes, the poor image quality, presence of cleft lip or palate, any osseous disease of cranio-facial region, previous orthognathic surgery.

Determination of measurement points

CBCT data sets were reformatted to a $20-\mathrm{mm}$ thick CBCT panoramic view (CBCT-pan) and 0.4-mm cross-sections that includes condyle, coronoid and sigmoid notch. The axial plane was positioned to pass through the sigmoid notch. The perpendicular distance between the fixed plane and upper limit of lingula or the upper point of the mandibular foramen was measured (Figure $1 \mathrm{a} / \mathrm{b} / \mathrm{c}$ ).

\section{Statistical Analysis}

All data were evaluated using the Statistical Package for the Social Sciences (SPSS version 20.0 for Windows, Chicago, Illinois, USA). Shapiro-Wilk statistics were used for the normality test. Descriptive statistics of age, gender, the perpendicular distance between the fixed plane and upper limit of lingula or the upper point of the mandibular foramen were performed.

The differences according to genders were analysed independent t-test. Right and left side measurements were compared with using paired-t test. In our evaluations statistical significance was set at 0.05 , therefore, $\mathrm{p}<0.05$ denotes significant difference between groups, and $p>0.05$ denotes absence of significant difference between groups.

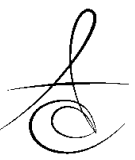




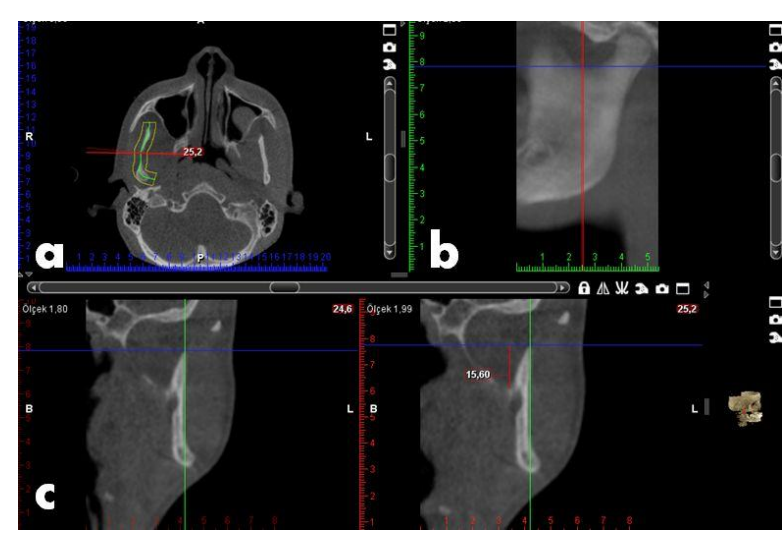

Figure 1

a: CBCT data sets were reformatted to a $20-\mathrm{mm}$ thick CBCT panoramic view (CBCT-pan) and $0.4-\mathrm{mm}$ cross-sections that includes condyle, coronoid and sigmoid notch.

b: The axial plane was positioned to pass through the sigmoid notch.

c: The perpendicular distance measurement between the fixed plane and upper limit of lingula or the upper point of the mandibular foramen.

\section{RESULTS}

Our study was performed on 140 segments of 70 patients between the ages of 12 and 28 years (mean age \pm std. dev. $=16.51 \pm 3.06$ ); of those, 32 were male (45.7\%) and 38 were female (54.3\%). The mean age of the men were $16.32 \pm 3.18$, and the mean age of the women were $16.68 \pm 2.99$.

The minimum distance of the between fixed plane passing from sigmoid notch with lingula was found as a minimum of 4.80 and a maximum of 19.20 (mean \pm std. dev. $=11.99 \pm 2.40, n=140$ ). The right and left side measurement ranged from 4.80 to 16.4 (mean \pm std. dev=11.34 $\pm 2.26, \mathrm{n}=70$ ) and from 7.72 to 19.20 (std. dev. $=12.64 \pm 2.39, \mathrm{n}=70$ ) respectively. The minimum and maximum values in men/women and total population are shown in Table 1.

When the comparative statistics are performed according to side, a statistically significant difference was detected ( $p<0.005)$. The distance of the between fixed plane passing from sigmoid notch with lingula on the left side were statistically significantly higher. But no statistically difference was detected according to gender.
Table 1. The distrubution of measurements according to gender

\begin{tabular}{|c|c|c|c|c|c|c|}
\hline \multicolumn{2}{|c|}{ Gender } & $\mathrm{N}$ & $\begin{array}{c}\text { Minimu } \\
\mathrm{m}\end{array}$ & $\begin{array}{c}\text { Maximu } \\
\mathrm{m}\end{array}$ & $\begin{array}{c}\text { Mea } \\
\mathrm{n}\end{array}$ & $\begin{array}{c}\text { Std. } \\
\text { Deviati } \\
\text { on }\end{array}$ \\
\hline \multirow{3}{*}{ Male } & Right & 32 & 4.80 & 16.40 & 11.56 & 2.47 \\
\cline { 2 - 7 } & Left & 32 & 7.72 & 19.20 & 12.47 & 2.78 \\
\cline { 2 - 7 } & Age & 32 & 12.00 & 28.00 & 16.31 & 3.18 \\
\hline \multirow{3}{*}{ Female } & Right & 38 & 6.00 & 16.20 & 11.17 & 2.08 \\
\cline { 2 - 7 } & Left & 38 & 8.20 & 16.80 & 12.79 & 2.03 \\
\cline { 2 - 7 } & Age & 38 & 13.00 & 28.00 & 16.68 & 2.99 \\
\hline \multirow{3}{*}{ Total } & Right & 70 & 4.80 & 16.40 & 11.34 & 2.26 \\
\cline { 2 - 7 } & Left & 70 & 7.72 & 19.20 & 12.64 & 2.39 \\
\cline { 2 - 7 } & Age & 70 & 12.00 & 28.00 & 16.51 & 3.06 \\
\hline
\end{tabular}

\section{DISCUSSION}

BSSRO currently is the most commonly used procedure for orthognathic surgery to correct jaw deformities. In this technique, the mandibular ramus is divided into both sides in the sagittal plane, and the distal fragment is moved forward or backward to correct the bite ${ }^{10}$.

In BSSRO, subperiosteal dissection was performed on the ramus superior, medial, and lateral, the next important step is to locate the lingula. This structure can be visualized directly when the soft tissues are adequately retracted medially with a (generally Seldin retractor) retractor; however, at times, this is very difficult to achieve ${ }^{8}$.

The initial cut on the lingual aspect of the mandible requires greater vertical or downward orientation than does a typical oblique tangential cut into the retrolingual recession ${ }^{11}$.

When a comminuted fracture occurs, as, for example, with a large buccal cortical plate fracture plus a separate condylar segment, the limited visual area permits just a few treatment options. If reoperation after healing is attempted, the delay in treatment may have deleterious consequences. But if immediate repair is attempted through large extraoral facial or cervical incisions, the advantage of direct visualization of the segments requiring reduction has to be weighed against the obvious inherent risks involving facial nerve damage, scarring, or both ${ }^{8}$.

BSSRO is probably the most commonly used procedure for the correction of mandibular dentofacial deformities. Although there have been many improvements in the technique within 30 years of the procedure, various complications still occur. The most

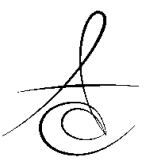


frequent complications include undesired fractures during surgery, paresthesia, and relapse ${ }^{12}$.

There are many retrospective and morphologic studies evaluating of mandibular anatomy associated with undesired fracture in BSSRO 9, 12-16.

Wang et al. ${ }^{9}$ and Aarabi et al. ${ }^{13}$ reported that compared with normal group undesired fracture group exhibited significantly shorter sigmoid notch and inferior border of mandible. However, the researchers did not evaluate the distance between lingula and sigmoid notch.

Shaeran et al. ${ }^{17}$ reported that prognathic mandible has higher lingula level.

Smith et al. ${ }^{12}$ in their study on 50 dried intact adult mandibles of unknown gender have found the mean value of medullary bone measurements between sigmoid notch and lingula as $7.5 \mathrm{~mm} \pm$ $3.9 \mathrm{~mm}$. In our study, the mean value of measurements between sigmoid notch and lingula was $11.99 \mathrm{~mm} \pm 2.40 \mathrm{~mm}$. We measured the total bone height in our study. In addition, our study population consisted of young individuals because the orthognatic surgery population was younger.

Due to the variable anatomy of the mandible and its relation to important anatomical structures, the procedure still presents technical difficulties leading to both intraoperative and postoperative complications. The rate of complications depends on the experience of the maxillofacial surgeon, as it requires intensive learning and practice ${ }^{18}$.

Generally, the orthopantomogram is considered as part of the preoperative evaluation of mandibular structures. Previous studies based on standardized norms and two-dimensional representation of three-dimensional (3D) changes has not been able to answer many questions about response to treatment and factors affecting skeletal remodeling. Two-dimensional imaging has proved to be problematic when evaluating the anatomy of the bone. In addition, magnifications and superpositions that prevent accurate measurements can be considered a disadvantage. The application of 3D imaging of the craniofacial complex in prospective controlled trials can be considered as one of the important advances in the investigation of complete diagnosis, treatment planning and outcome evaluation. Computed tomography (CT) can be used where surgeons need $3 \mathrm{D}$ evaluation of the bone before the surgery. However, CT imaging is not suitable for routine use due to its high cost and higher radiation exposure. Research using $\mathrm{CBCT}$ in orthodontics and oral maxillofacial surgery has shown that this new tool can improve the determination of mandibular anatomy position before and after orthognathic surgery. CBCT provides the opportunity for the surgeon to find the neurovascular bundle in three dimensions, making it possible to individual modification of the lower boundary approach depending on the distance from the neurovascular bundle to the lower border and the buccal plate ${ }^{17,19 \text {, }}$ 20.

In conclusion, 140 segments were evaluated for this study with aid of CBCT. This study revealed that the safe distance for BSSRO may range from 4.8 $\mathrm{mm}$ to $19.2 \mathrm{~mm}$ in Turkish population.

The measurement of the perpendicular distance between the fixed plane and upper limit of lingula with $\mathrm{CBCT}$ provides useful preoperative information and must be known before BSSRO.

İ.Şevki Bayrakdar : ORCID ID: /0000-0001-5036-9867 Elif Bilgir: ORCID ID: 0000-0001-9521-4682

\section{REFERENCES}

1. Baek SM, Kim SS, Bindiger A. The prominent mandibular angle: preoperative management, operative technique, and results in 42 patients. Plast Reconstr Surg 1989;83:272-80.

2. Deguchi M, Iio Y, Kobayashi K, Shirakabe T. Anglesplitting ostectomy for reducing the width of the lower face. Plast Reconstr Surg 1997;99:1831-9.

3. Ertas Ü, Saruhan N, Yalçin E. Surgical treatment of class iii malocclusion: monozygotic twin. J Craniofac Surg 2016;27:e471-e3.

4. Dal Pont G. Retromolar osteotomy for correction of prognathism. J Oral Surg 1961;19:42-7.

5. Hunsuck E. A modified intraoral sagittal splitting technique for correction of mandibular prognathism. J Oral Surg 1968;26:249-52.

6. Epker B. Modifications in the sagittal osteotomy of the mandible. J Oral Surg 1977;35:157-9.

7. Mehra P, Castro V, Freitas RZ, Wolford LM. Complications of the mandibular sagittal split ramus osteotomy associated with the presence or absence of third molars. J Oral Maxillofac Surg 2001;59:854-8. 
8. Joseph P. McCain KK. Endoscopic oral and maxillofacial surgery. in: shahrakh c. bagheri rbb, husain ali khan., editor. curr theraphy oral maxillofac surg. United Kiingdom: Saunders; 2012. p. $45-7$.

9. Wang $\mathrm{T}^{1}$, Han JJ, Oh HK, Park HJ, Jung S, Park YJ, Kook MS. Evaluation of mandibular anatomy associated with bad splits in sagittal split ramus osteotomy of mandible. J Craniofac Surg 2016; 27:e500-e4.

10. Blomqvist JE, Alberius $P$, Isaksson S. Sensibility following sagittal split osteotomy in the mandible: a prospective clinical study. Plast Reconstr Surg 1998;102:325-33.

11. Lee. JJ. Mandibular Asymmetry: diagnosis and treatment considerations. In: shahrakh c. bagheri rbb, husain ali khan., editor. curr Theraphy Oral Maxillofac Surg. United Kingdom: Saunders; 2012. p. 617-84.

12. Smith BR, Rajchel JL, Waite DE, Read L. Mandibular ramus anatomy as it relates to the medial osteotomy of the sagittal split ramus osteotomy. J Oral Maxillofac Surg 1991;49:112-6.

13. Aarabi M, Tabrizi R, Hekmat M, Shahidi S, Puzesh A. Relationship between mandibular anatomy and the occurrence of a bad split upon sagittal split osteotomy. J Oral Maxillofac Surg 2014; 72:250813.

14. Trost O, Kazemi A, Cheynel N, Benkhadra M, Soichot P, Malka G, Trouilloud P. Spatial relationships between lingual nerve and mandibular ramus: original study method, clinical and educational applications. Surg Radiol Anatomy 2009;31:447-52.

15. Fujimura K, Segami N, Kobayashi S. Anatomical study of the complications of intraoral verticosagittal ramus osteotomy. J Oral Maxillofac Surg 2006;64:384-9.

16. Yeh AY, Finn BP, Jones RH, Goss AN. The variable position of the inferior alveolar nerve (IAN) in the mandibular ramus: a computed tomography (CT) study. Surg Radiologic Anatomy 2018:1-13.

17. Shaeran TAT, Shaari R, Rahman SA, Alam MK, Husin AM. Morphometric analysis of prognathic and non-prognathic mandibles in relation to BSSO sites using CBCT. J Oral Biolog Craniofacial Res 2017;7:7-12.
18. Sahoo N, Kaur P, Roy I, Sharma R. Complications of sagittal split ramus osteotomy. J Oral Maxillofac Surg, Medicine Pathol 2017;29:100-4.

19. Agbaje JO, Sun Y, De Munter S, Schepers S, Vrielinck L, Lambrichts I, et al. CBCT-based predictability of attachment of the neurovascular bundle to the proximal segment of the mandible during sagittal split osteotomy. Int J oral maxillofac surg. 2013;42:308-15.

20. Motta ATSd, Carvalho FdAR, Cevidanes LHS, Almeida MAdO. Assessment of mandibular advancement surgery with 3D CBCT models superimposition. Dent Press J Orthod. 2010; 15: e1-12.

\section{Yazışma Adresi}

Dr. Öğr. Üyesi İbrahim Şevki Bayrakdar, Eskişehir Osmangazi University, Faculty of Dentistry, Department of Dentomaxillofacial Radiology, Eskişehir -Turkey.

Phone: +905064704248

e-mail: ibrahimsevkibayrakdar@gmail.com 